\title{
USE OF THERMODYNAMIC PARAMETERS OF Q-I ISOTHERMS TO EVALUATE OF K-AVAILABILITY IN SOME EGYPTIAN SOILS
}

\section{Haidy Emad El-Dean ${ }^{1 *}$, Shawky M. Metwally ${ }^{1}$, Mohamed H. El-Mancy ${ }^{1}$, Magdy M. Mohamed ${ }^{2}$ and Mohamed Ayman ${ }^{1}$}

1. Department of Water And Soil Science, Faculty of Technology \& Development Zagazig University, Egypt.

2. Ismailia Research Center, Ismailia, Egypt.

Corresponding author: e mail: ehaidy23@gmail.com,

\section{ABSTRACT:}

Quantity-intensity $(Q / I)$ isotherms were applied to evaluate the availability of $\mathrm{K}^{+}$in four different Egyptian soils. Wheat plant was used as an indicator to achieve this goal. After wheat sowing, soils were fertilized by $\mathrm{K}_{2} \mathrm{SO}_{4}$ at different rates of 0, 50, 100 and $150 \%$ of wheat's fertilizer recommendation.

The obtained results showed that increasing added $K^{+}$ concentrations led to increase the activity ratio of $K^{+}\left(A R_{K}{ }^{0}\right)$ and corresponding changes in labile $K^{+}(K)$ at equilibrium. The equilibrium activity ratio of $K^{+}\left(A R_{K}{ }^{0}\right)$ varied between $2.88-15.01 \times 10^{-3}\left(\mathrm{~mol} \mathrm{~L}^{-1}\right)^{0.5}$ in initial stage and $1.39-17.31 \times 10^{-3}\left(\mathrm{~mol} \mathrm{~L}^{-1}\right)^{0.5}$ in the last stage. The labile $K^{+}\left(K_{L}\right)$ fraction ranged from $0.047-0.456$ and $0.02-0.45 \mathrm{cmol}$ $\mathrm{kg}^{-1}$ before sowing and at harvesting time of wheat plant, respectively. The potential buffering capacities of $K^{+}\left(P B C_{K}\right)$ fluctuated from $16.3-30.4$ and $11.9-29.9 \mathrm{cmol} \mathrm{kg}^{-1}\left(\mathrm{~mol} \mathrm{~L}^{-1}\right)^{-0.5}$ before sowing and at harvesting stage of wheat plant. The free energy of $K^{+}$exchange $(-\Delta G)$ ranged from

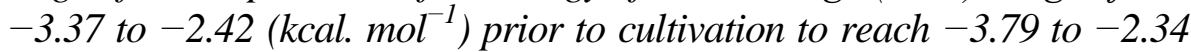

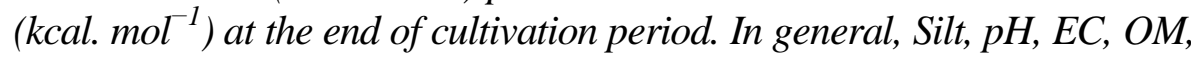
Soluble $\mathrm{K}, \mathrm{NH}_{4} \mathrm{OAcK}$ and $\mathrm{HNO}_{3} \mathrm{~K}$ exhibited substantial correlations with $K_{L} P B C_{K}, A R_{K}^{0}, K_{G}$ and $\triangle G$, whereas $p H$ had inverse correlation with mentioned parameters, except $K_{G}$. Furthermore, a substantial correlation was observed between thermodynamic characteristics of $K$ extracted by $\mathrm{H}_{2} \mathrm{O}, 1 \mathrm{M} \mathrm{NH}_{4} \mathrm{OAc}$ and $1 \mathrm{M} \mathrm{HNO}$.

Conclusively: from these results it could be concluded that, significant correlation of the tested thermodynamic parameters with physicochemical soil characteristics. Thus, the study contributed significantly to practical $K^{+}$management by providing important information on $\mathrm{K}^{+}$dynamics in typical Egyptian soils.

Keywords: Q/I relations; -Thermodynamic parameters of $\mathrm{K}$; forms of K; Activity ratio of K; Gibb's Free Energy. 


\section{INTRODUCTION}

For all plants, potassium (K) is one of the most essential macronutrients. Except for nitrogen, it is taken up by plants in amounts that may surpass those of the other elements. According to the necessary nutrient requirements for most plants, it is a vital component for all plants. (Manahan, 2017). It also has a significant impact on agricultural output, both in terms of quantity and quality.

The study of $\mathrm{K}$-behavior in soils is important because of its importance for plants especially the development of farming towards intensive agriculture. As a result, it is now important to reevaluate $K$ supply capacity on a thermodynamic basis to identify $\mathrm{K}$ availability by evaluating soil $\mathrm{K}$ using intensity/quantitative $(\mathrm{Q} / \mathrm{I})$ characteristics. In an attempt to describe the mechanisms of $\mathrm{K}$ release and fixation from the soil solid phase to the soil solution phase, the Quantity-Intensity relationship (Q/I) was first introduced by (Woodruff, 1955b) and further developed by (Beckett, 1964a,b) as a specialized version of sorption curves experimentation for describing $\mathrm{K}$ potential buffering characteristics. Although the universality of scope in forecasting available $\mathrm{K}$ has sometimes been questioned, quantity intensity experiments remain one of the primary tools in understanding $\mathrm{K}$ dynamics in soils over seven decades since these original efforts. This explains why a lot of newly published research on $\mathrm{K}$ dynamics still looks at the availability of $\mathrm{K}$ via the perspective of the Q/I relationship (Islam et al., 2017; Panda \& Patra, 2018; Das et al., 2019; Jiang et al., 2019; Suttanukool et al., 2019; Zhu et al., 2020). Parameters included from $\mathrm{Q} / \mathrm{I}$ isotherms include equilibrium activity ratio $\left(\mathrm{AR}_{\mathrm{K}}\right)$ which is a measure of $\mathrm{K}$ soil solution intensity (Intensity Factor), a quantity (Quantity Factor) parameter $\left(\Delta \mathrm{K}_{0}\right)$ which is assumed to represent soil labile $\mathrm{K}\left(\mathrm{K}_{\mathrm{L}}\right)$, and the potential buffering capacity $\left(\mathrm{PBC}_{\mathrm{K}}\right)$, which is an indicator of soil's buffering ability to resist soil solution $\mathrm{K}$ changes. Furthermore, Gibb's free energy of exchange $(\Delta G)$ is the amount of energy released when one equivalent of $\mathrm{K}$ in the standard state is replaced by equivalents of $\mathrm{Ca}$ and/or $\mathrm{Mg}$ in the soil solid phase. According to Evangelou et al. (1994) in their thorough review on the $\mathrm{Q} / \mathrm{I}$ connections $\left(\mathrm{K}_{\mathrm{G}}\right)$, several recent research has utilized thermodynamic criteria to assess the availability of $\mathrm{K}$ in soil, but conventional techniques of assessing the quantity of $\mathrm{K}$ suitable for extraction after employing $1 \mathrm{M} \mathrm{NH}_{4} \mathrm{OAc}$ have limited its application. In many situations, a quantitative criterion like this did not provide the desired result (Cooke, 1979). As a result, scientists began using thermodynamic criteria, which are thought to be a more accurate means of determining how much soil can supply. Furthermore, Wang et al. (2004), Pasricha \& Bansal (2002), Surapaneni et al. (2002), Samadi (2006), Zarrabi \& Jalali (2008), Al obidi et al. (2011) shown that K dynamics between the solid and liquid phases of soils are 
influenced by the ion-exchange theory for the ions $\mathrm{K}^{+}, \mathrm{Ca}^{2+}+\mathrm{Mg}^{2+}$. We can compute several thermodynamic parameters (i.e., $-\Delta \mathrm{G}, \mathrm{PBC}_{\mathrm{K}}, \mathrm{K}_{\mathrm{L}}, \mathrm{AR}_{\mathrm{K}}$ ) that may be utilized to determine the $\mathrm{K}$ fertilizer demands of soils utilizing ionic exchange. As the effectiveness ratios represent it in the releasable storage (Beckett, 1964b; Sparks, 2000), specialized and nonspecialized sites (Sparks, 2000; Wang et al., 2004) that play an important role in providing $\mathrm{K}$ to the liquid soil phase (Subba \& Srivastava, 2001). Either Khamis (2000) or Al obidi et al. (2011) demonstrated that thermodynamic characteristics may be utilized to assess $\mathrm{K}$ levels in soil solids and solutions. Cation exchange capacity (CEC) alone may not be able to show the true condition of soils when $\mathrm{K}$ fixation and liberation are dominant in terms of biological features (Beckett et al., 1966a). One of the fundamental approaches used to study K's PBC was outlined in the papers of the K International Institute (Krauss, 2002). Clay soils contained more K than sand soils, according to Krauss (2002), while Wang et al. (2004) noted that $\mathrm{AR}_{\mathrm{K}}$ represents the concentration of $\mathrm{K}$ in soils characterized by their liquid-solid phase equilibrium.

As a result, the goal of the study was to investigate the availability of $\mathrm{K}$ using various thermodynamic characteristics, as well as its relationship to soil characteristics of several typical Egyptian soils and their influence on wheat yields produced in such soils.

\section{MATERIALS \& METHODS}

\section{The experiment location and treatments:}

Four different types of typical Egyptian soils were used in a pot experiment at the Ismailia Research Station Farm (Location: 30 39'32.2"N $32^{\circ} 14^{\prime} 54.9^{\prime \prime E}$ ). Soil samples were taken from several sites (Locations: $30^{\circ} 29^{\prime} 04.9^{\prime \prime} \mathrm{N} \quad 32^{\circ} 04^{\prime} 37.0^{\prime \prime} \mathrm{E} ; \quad 30^{\circ} 32^{\prime} 33.6^{\prime \prime} \mathrm{N} \quad 32^{\circ} 12^{\prime} 09.4^{\prime \prime} \mathrm{E} ; \quad 30^{\circ} 34^{\prime} 36.6^{\prime \prime} \mathrm{N}$ $\left.32^{\circ} 08^{\prime} 29.9^{\prime \prime} \mathrm{E} ; 30^{\circ} 21^{\prime} 14.3^{\prime \prime} \mathrm{N} 30^{\circ} 00^{\prime} 46.8^{\prime \prime} \mathrm{E}\right)$. The studied soils differed in texture, physicochemical properties, and $\mathrm{K}$ thermodynamic parameters, as shown in Table 1. Figure 1 presents the initial plot of the quantity-intensity relationship in tested soils. Soil samples were placed in plastic pots (5 kilograms each) and fertilized with the recommended nitrogen (Urea $46 \% \mathrm{~N}$ ) and phosphorus (P) (Calcium monophosphate $15 \% \mathrm{P}_{2} \mathrm{O}_{5}$ ). On December 4, 2018, wheat seeds (Triticum aestivum Var. Misr 1) were sowed. During the 2018/2019 winter season, the soils were watered once a week. According to the Egyptian Ministry of Agriculture and Land Reclamation, soils were fertilized with $\mathrm{K}_{2} \mathrm{SO}_{4}\left(46 \% \mathrm{~K}_{2} \mathrm{O}\right)$ at rates of $0,50,100,150 \%$ of recommended rate and 
Table (1): Initial characteristics and thermodynamic parameters of the tested soils.

\begin{tabular}{|c|c|c|c|c|}
\hline Property & Soil 1 & Soil 2 & Soil 3 & Soil 4 \\
\hline \multicolumn{5}{|l|}{ Particles size distribution $\left(\mathrm{g} \mathrm{hg}^{-1}\right)$} \\
\hline Sand & 80.5 & 37.5 & 12.5 & 44.5 \\
\hline Silt & 18.0 & 51.0 & 48.0 & 48.0 \\
\hline Clay & 1.5 & 11.5 & 39.5 & 7.5 \\
\hline Texture $^{1}$ & Sandy & Silty loam & Silty clay loam & Loamy \\
\hline $\mathrm{pH}^{2}$ & 8.22 & 7.89 & 7.87 & 8.21 \\
\hline $\mathrm{EC}^{3}\left(\mathrm{dS} \mathrm{m}^{-1}\right)$ & 2.87 & 3.88 & 3.08 & 3.82 \\
\hline $\mathrm{CaCO}_{3}\left(\mathrm{~g} \mathrm{Kg}^{-1}\right)$ & 12.60 & 25.21 & 21.03 & 184.84 \\
\hline Organic matter $\left(\mathrm{g} \mathrm{Kg}^{-1}\right)$ & 1.61 & 1.93 & 12.01 & 2.41 \\
\hline $\mathrm{CEC}\left(\mathrm{cmol} \mathrm{Kg}{ }^{-1}\right)$ & 10.12 & 16.86 & 24.16 & 13.25 \\
\hline \multicolumn{5}{|l|}{ Extractable $\mathrm{K}\left(\mathrm{cmol} \mathrm{Kg}^{-1}\right)$ by: } \\
\hline $\mathrm{H}_{2} \mathrm{O}-\mathrm{K}$ & 0.022 & 0.037 & 0.045 & 0.031 \\
\hline $\mathrm{NH}_{4} \mathrm{OAc}-\mathrm{K}$ & 0.197 & 0.732 & 0.756 & 0.412 \\
\hline $\mathrm{HNO}_{3}-\mathrm{K}$ & 0.292 & 1.456 & 2.897 & 0.578 \\
\hline \multicolumn{5}{|l|}{ Some thermodynamic parameters } \\
\hline $\mathrm{K}_{\mathrm{L}}\left(\mathrm{cmol} \mathrm{kg}^{-1}\right)$ & 0.047 & 0.259 & 0.456 & 0.187 \\
\hline $\mathrm{PBC}_{\mathrm{K}}\left(\mathrm{cmol} \mathrm{kg}^{-1}\right) /\left(\mathrm{mol} \mathrm{L}^{-1}\right)^{0.5}$ & 16.30 & 25.2 & 30.4 & 18.2 \\
\hline $\mathrm{AR}_{\mathrm{K}}^{0}\left(\mathrm{~mol} \mathrm{~L}^{-1}\right)^{0.5} \times 10^{-3}$ & 2.883 & 10.258 & 15.007 & 10.247 \\
\hline Relative affinity for $\mathrm{K}(\mathrm{L} \mathrm{mol})^{0.5}$ & 1.611 & 1.495 & 1.258 & 1.374 \\
\hline$-\Delta \mathrm{G}\left(\mathrm{kcal} . \mathrm{mol}^{-1}\right)$ & -3.37 & -2.64 & -2.42 & -2.64 \\
\hline
\end{tabular}

in two doses (early and middle of the season). Wheat plants were harvested, separated, dried, and weighed during the harvest stage.

\section{Methodology:}

\subsection{Laboratory analyses:}

Particle size distribution was assessed using a soil hydrometer method, $\mathrm{pH}$ was measured using a $\mathrm{pH}$ meter, organic matter was quantified using a wet oxidation technique $\left(\mathrm{H}_{2} \mathrm{CrO}_{7}\right)$, and $\mathrm{CaCO}_{3}$ was determined using a back-titration method. The titration technique with $\mathrm{EDTANa}_{2}$ was used to determine $\mathrm{Ca}^{2+}+\mathrm{Mg}^{2+}$. The electrical conductivity of the soil paste extract was also measured using an $\mathrm{EC}$ meter. Potassium $(\mathrm{K})$ was measured using a flame

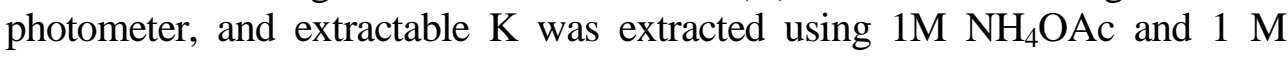
$\mathrm{HNO}_{3}$ according to the description of Estefan et al. (2013). 


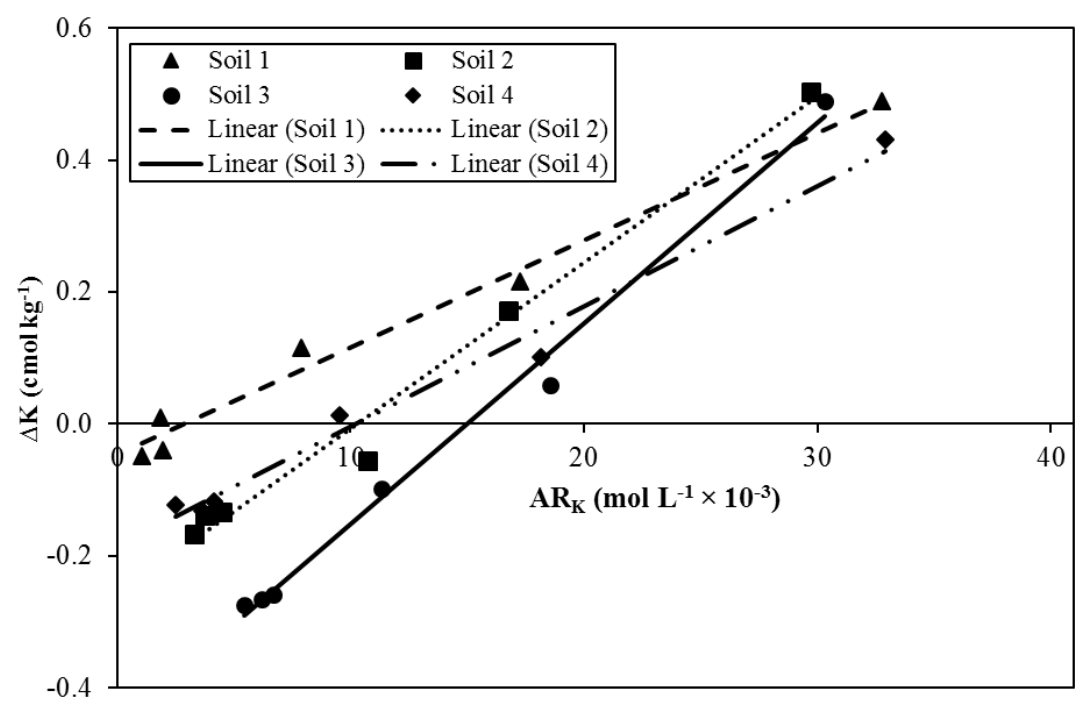

Fig. (1): Initial Quantity-Intensity plot of the tested soil.

According to Beckett's procedure, the exchange equilibrium state of $\mathrm{K}$ was investigated between the liquid and solid phases of soil (1964b). Five grams of oven-dried soil was mixed with $50 \mathrm{ml}$ of $0.01 \mathrm{M} \mathrm{CaCl}_{2}$ solution with $0.0,0.1,0.2,1.0,2.0$ and $4.0 \mathrm{mM} \mathrm{KCl}$ solution. The samples were agitated for 3 hours, then equilibrated for 24 hours before being extracted the next day.

\subsection{Calculation methods:}

The parameters were calculated based on the below equations:

a- Ionic strength (I) was calculated According to (Griffin \& Jurinak, 1973):

$I=0.0129 E C(d S / m)$

[Eq. 1]

Where: $I$; is ionic strength, $E C$ is electrical conductivity.

b- Activity coefficient of K ( $\log \gamma \boldsymbol{i})$ was calculated according to Extended Debye-Huckel equation as:

$\log \gamma i=-A Z i^{2} \frac{\sqrt{I}}{(1+B d i \sqrt{I})} \quad$ [Eq. 2]

$\log \gamma_{i}$ is the activity coefficient of $\mathrm{K}, A=0.509, Z_{i}$ is a charge of the ion, $\mathrm{I}$ is ionic strength, $\mathrm{B}$ is 0.33 , and $\mathrm{d}_{\mathrm{i}}$ is ion diameter

c-Activity of $\mathrm{K}^{+}\left(a_{i}\right)$ :

$a_{i}=\gamma_{i} m_{i}$

[Eq. 3]

Where: $a_{i}$ is $\mathrm{K}$ - activity, $\gamma_{\mathrm{i}}$ is coefficient of $\mathrm{K}-$ activity, and $\mathrm{m}_{\mathrm{i}}$ is a concentration of $\mathrm{K}(\mathrm{M})$

d- Activity ratio of $\mathrm{K}^{+}\left(\mathrm{AR}_{\mathrm{K}}\right)$ :

$\mathbf{A} \mathbf{R}_{\mathbf{K}}=\frac{a K}{\sqrt{(a C a+a M g)}}$

[Eq. 4] 
Where: $a K$ is $\mathrm{K}$-activity, $a C a$ is $\mathrm{Ca}-$ activity, and $a M g$ is $\mathrm{Mg}-$ activity.

e- Gibb's Free energy $(\Delta \mathbf{G})$ was calculated According to (Woodruff, 1955b)

$\Delta \mathrm{G}\left(\mathrm{cal} \mathrm{mol}^{-1}\right)=\mathrm{RT} \ln \mathrm{AR}_{\mathrm{K}}{ }^{0} \quad$ [Eq. 5]

Where: $\mathrm{R}$ is the universal gas constant, $\mathrm{T}$ is the absolute temperature.

f- Gabon selectivity coefficient $\left(\mathrm{K}_{\mathrm{G}}\right.$ or relative affinity) was calculated According to (Sparks, 1998)
$\mathrm{K}_{\mathrm{G}}=\frac{P B C k}{C E C}$
[Eq. 6]
$\mathrm{PBC}_{\mathrm{K}}=\frac{\Delta \mathrm{K}}{A R K}$
[Eq. 7]

\section{Statistical analysis}

All data were statistically analyzed according to the variance analysis technique for the randomized completely plot design, correlation, and regression coefficients using the SPSS V. 26 software package. The significant differences between the mean values of treatments were achieved by the LSD method.

\section{RESULT \& DISCUSSION}

\section{Impact of some soil properties on thermodynamic parameters of $K$ :}

Tables 1 and 2 show some of the physicochemical and thermodynamic parameters of the investigated soils before planting (Table 1) and after harvest (Table 2). Most physicochemical parameters, such as $\mathrm{pH}, \mathrm{EC}, \mathrm{CEC}, \mathrm{CaCO}_{3}$, organic matter, and soil texture, differed in the investigated soil. In general, soil 3 had the highest clay content, organic matter and $\mathrm{CEC}$. $\mathrm{CaCO}_{3}$ differed among the tested soils, which gave the highest value in soil 4 (a calcareous soil) and the lowest in soil 1 (a non-calcareous one).

The concentration of extracted $\mathrm{K}$ differed according to the used extraction method (water, $1 \mathrm{M} \mathrm{NH}_{4} \mathrm{OAc}$ and $1 \mathrm{M} \mathrm{HNO}_{3}$ ). In the initial stage of the season, soils $1,2,3$, and 4 recorded $0.022,0.037,0.045,0.031 \mathrm{cmole} \mathrm{kg}^{-1}$ for $\mathrm{H}_{2} \mathrm{O}$ extraction, $0.197,0.732,0.756,0.412 \mathrm{cmole} \mathrm{kg}^{-1}$ for $1 \mathrm{M} \mathrm{NH}_{4} \mathrm{OAc}$ extraction, and $0.292,1.456,2.897,0.578 \mathrm{cmole} \mathrm{kg}^{-1}$ for $1 \mathrm{M} \mathrm{HNO}_{3}$ extraction (Table 1), respectively. Clay loam soil (soil 3) had the highest value, whereas sandy soil had the lowest concentrations (soil 1). Furthermore, $\mathrm{K}_{\mathrm{L}}$ values in the studied soils were lower during harvest than at beginning of the experiment. Soil 3 had a higher potential buffering capacity of $\mathrm{K}\left(\mathrm{PBC}_{\mathrm{K}}\right)$ values than soil 1 . For soil 3 and the other three soils, the highest $\mathrm{AR}_{\mathrm{K}}{ }^{0}$ value was $0.015(\mathrm{~mol}$ $\left.\mathrm{L}^{-1}\right)^{0.5}$ and the lowest was $0.0028\left(\mathrm{~mol} \mathrm{~L}^{-1}\right)^{0.5}$, respectively. In the case of relative affinity or $\mathrm{K}_{\mathrm{G}}$ and $\Delta \mathrm{G}$, the scenario was reversed, soil 1 recorded the 


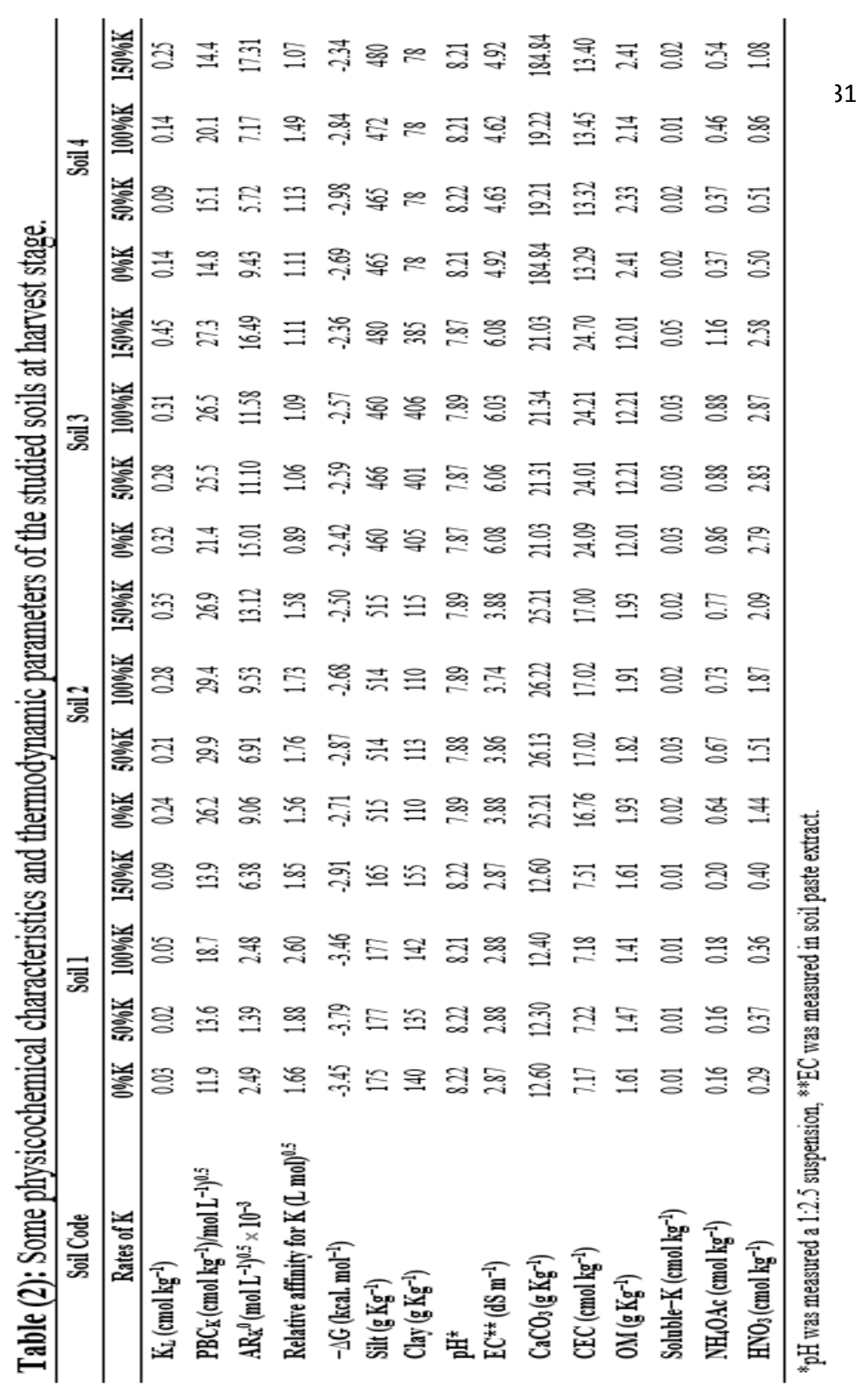


highest, while soil 3 gave the lowest is 1.61 and $1.26(\mathrm{~L} \mathrm{~mol})^{0.5}$, respectively, and concerning $-\Delta \mathrm{G}$, the registered values being negatively associated with above-named parameters and so, the greatest and lowest value of -2.42 and $3.37 \mathrm{kcal} \mathrm{mol}^{-1}$ realized in soil 1 and soil 3, respectively in the first stage.

The labile $\mathrm{K}_{\mathrm{L}}$ values in the investigated soils changed during harvest, as shown in Table 2 and Fig. 2. For 0, 50, 100 and $150 \% \mathrm{~K}$ levels, the studied soil recorded values of $0.03,0.02,0.05,0.09 \mathrm{cmol} \mathrm{kg}^{-1}$ for soil $1,0.24,0.21,0.28$, $0.35 \mathrm{cmol} \mathrm{kg}^{-1}$ for soil 2, $0.32,0.28,0.31$, and $0.45 \mathrm{cmol} \mathrm{kg}^{-1}$ for soil 3 , and $0.14,0.09,0.14,0.25 \mathrm{cmol} \mathrm{kg}^{-1}$ for soil 4 . In sandy soil, the lower $\mathrm{K}_{\mathrm{L}}$ value was $0.02 \mathrm{cmol} \mathrm{kg}^{-1}$ of $50 \% \mathrm{~K}$ level in soil 1, while the higher value was $0.45 \mathrm{cmol}$ $\mathrm{kg}^{-1}$ by using a $150 \% \mathrm{~K}$ rate in soil 3 . The high clay, silt, surface area, CEC values, and a number of loosely bound $\mathrm{K}^{+}$ions present at the exchangeable site may be linked to the increased $\mathrm{K}_{\mathrm{L}}$ values (Simard et al., 1992; Khamis, 2000; Krauss, 2000; Samadi, 2006; Al-Salam \& AL-Kaysi, 2013; Hamed \& Amin, 2017). Furthermore, high labile $K$ levels resulted in an increase in $K$ availability due to increased $\mathrm{K}$ release into the soil solution. In addition, $\mathrm{K}$ fertilizer may increase the labile $\mathrm{K}$ in the soil (Yawson et al., 2011) since $\mathrm{K}$ fertilizers are fully soluble in soils. Furthermore, the lowest $K_{L}$ values soil 1-4 varied from 0.03 to $0.09 \mathrm{cmol} \mathrm{kg}^{-1}$. This could be due to the highest sand content in the soil. Because of their lower CEC or clay content compared to soil 3, therefore most of the K supplied by mineral fertilizer or released from organic amendments in calcareous or sandy soils (soil 1,4 ) is subjected to leaching (Hamed \& Amin, 2017). In regard to soil $1,2,3$ and 4 , values of $\mathrm{PBC}_{\mathrm{K}}$ were $11.9,13.6,18.7$, 13.90, $26.2 \mathrm{cmol} \mathrm{kg}^{-1} /\left(\mathrm{mol} \mathrm{L}^{-1}\right)^{0.5}, 26.2,29.9,29.4,26.9 \mathrm{cmol} \mathrm{kg}^{-1} /\left(\mathrm{mol} \mathrm{L}^{-1}\right)^{0.5}$ , 21.4, 25.5, 26.5, 27.3 $\left.\mathrm{cmol} \mathrm{kg}^{-1} /(\mathrm{mol} \mathrm{L})^{-1}\right)^{0.5}$ and $14.8,15.1,20.1,14.4 \mathrm{cmol}$ $\mathrm{kg}^{-1} /\left(\mathrm{mol} \mathrm{L}^{-1}\right)^{0.5}$ for $0,50,100,150 \% \mathrm{~K}$, respectively.

Furthermore, $\mathrm{PBC}_{\mathrm{K}}$ levels varied substantially from 11.9 to $29.9 \mathrm{cmol}$ $\left.\mathrm{kg}^{-1} /(\mathrm{mol} \mathrm{L})^{-1}\right)^{0.5}$. In addition, the Equilibrium activity ratio of $\mathrm{K}\left(\mathrm{AR}_{\mathrm{K}}{ }^{0}\right)$ is calculated to determine the intensity of a labile $\mathrm{K}\left(\mathrm{K}_{\mathrm{L}}\right)$ in the soil (Intensity factor) and represent the $\mathrm{K}$ that is accessible to crop roots immediately (Yawson et al., 2011).

Furthermore, potassium fertilization enhanced the activity ratio of $\mathrm{K}^{+}$ $\left(\mathrm{AR}_{\mathrm{K}}{ }^{0}\right)$ in equilibrium solutions in the investigated soil. At equilibrium, the concentration of $\mathrm{AR}_{\mathrm{K}}{ }^{0}$ varied from 1.39 to $17.31\left(\mathrm{~mol} \mathrm{~L}^{-1}\right)^{0.5} \times 10^{-3}$. In addition, the $\mathrm{K}^{+}$activity ratio $\left(\mathrm{AR}_{\mathrm{K}}{ }^{0}\right)$ provides a good estimation of $\mathrm{K}^{+}$ availability in soil. These variations in $\mathrm{K}^{+}$activity ratio $\left(\mathrm{AR}_{\mathrm{K}}{ }^{0}\right)$ in soils might be related to the changes in $\mathrm{K}^{+}$concentrations in equilibrating solutions, equilibration duration, $\mathrm{Ca}^{2+}$ and/or $\mathrm{Mg}^{2+}$ contents, and most likely variances in the mineralogical composition of the soils (Yawson et al., 2011). The $\mathrm{AR}_{\mathrm{K}}{ }^{0}$ is a measure of how much $\mathrm{K}^{+}$is available to plants. Increased $\mathrm{AR}_{\mathrm{K}}{ }^{0}$ levels are 

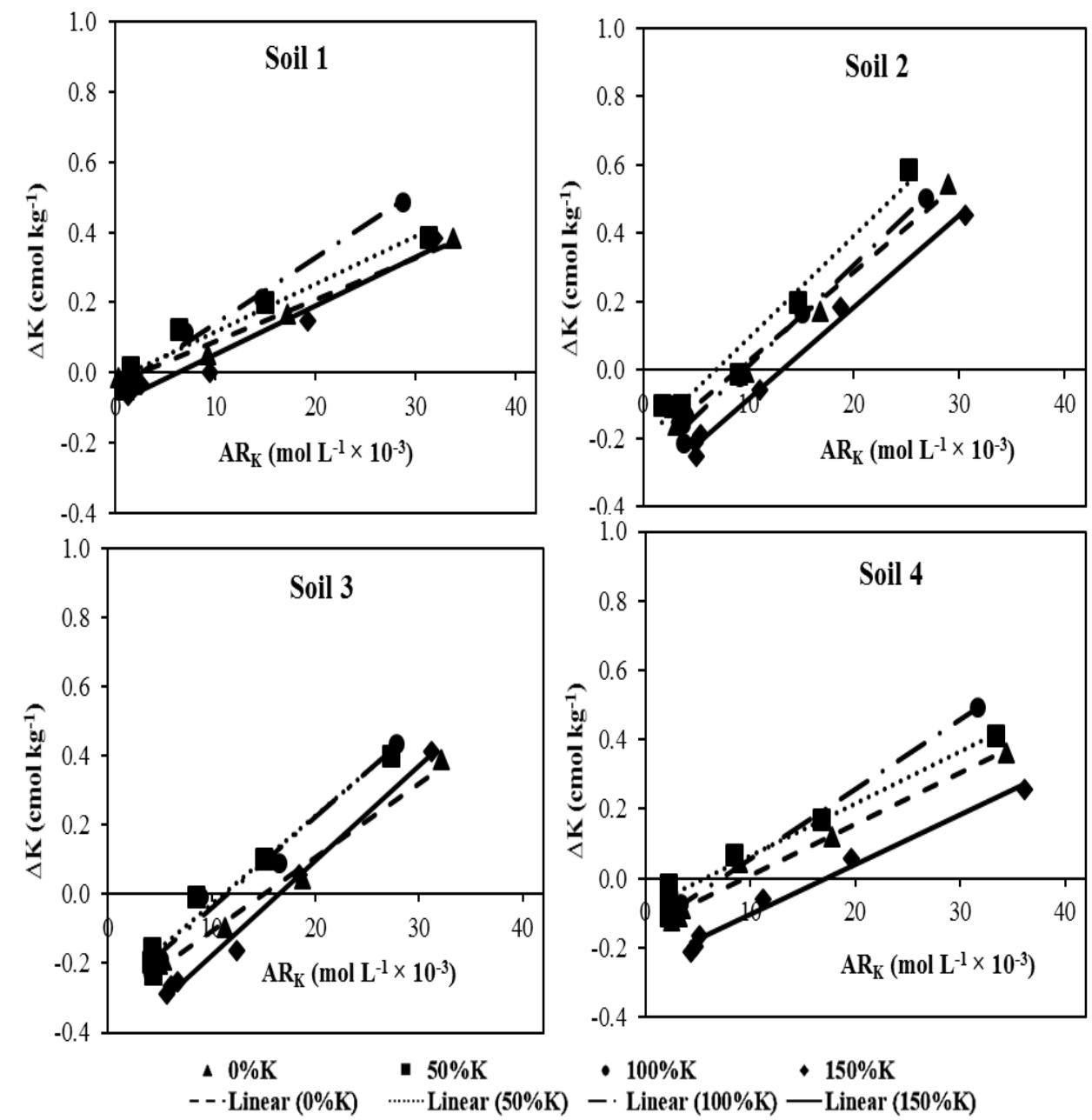

Fig. (2): Quantity-Intensity plots of the studied soil at harvest.

linked to higher $\mathrm{K}^{+}$ionic strength in solution and therefore higher $\mathrm{K}^{+}$ availability to plants in comparison to $\mathrm{Ca}^{2+}$ and $\mathrm{Mg}^{2+}$ cations (Beckett, $1964 \mathrm{a} \&$ b). In general, soils with high contents of exchangeable and non-exchangeable $\mathrm{K}^{+}$had higher $\mathrm{AR}_{\mathrm{K}}{ }^{0}$ values, while soils with lower contents of exchangeable and non-exchangeable $\mathrm{K}^{+}$had lower $\mathrm{AR}_{\mathrm{K}}{ }^{0}$ values (Jagadeesh et al., 2005; Panda \& Patra, 2018).

The lower levels of $\mathrm{AR}_{\mathrm{K}}{ }^{0}$ in some soils may be attributed to the presence of a higher number of particular $\mathrm{K}^{+}$sites that can fix $\mathrm{K}^{+}$(Abaslou \& Abtahi, 2008; Panda \& Patra, 2018). The highest values in soils 2 and 3 indicate that adsorbed $\mathrm{K}^{+}$was largely retained at planar positions, implying a higher $\mathrm{K}^{+}$ supply intensity and hence more $\mathrm{K}^{+}$being absorbed by plants more quickly. In 
contrast, because soils 1 and 4 have the highest sand concentration, there is a risk of $\mathrm{K}^{+}$leachability (Panda \& Patra, 2018). Furthermore, soil 1 with low levels of labile and nonlabile $\mathrm{K}^{+}$which exhibited low $\mathrm{AR}_{\mathrm{K}}{ }^{0}$ may respond to $\mathrm{K}^{+}$ fertilization. In this case, regular application of $\mathrm{K}^{+}$fertilizer at multiple dosages to $\mathrm{K}^{+}$deficient soils may be recommended. Additionally, relative affinity values $\left(\mathrm{K}_{\mathrm{G}}\right)$ of the exchange complex ranged between 0.89 to $2.60(\mathrm{~L} \mathrm{~mol})^{0.5}$. The average $\mathrm{K}_{\mathrm{G}}$ values for soil 1, 2, 3 and 4 were 2.00, 1.66, 1.04 and 1.20 (L $\mathrm{mol})^{0.5}$, respectively. Gibb's free energy $(-\Delta G)$ in soil samples differed substantially. Sandy soils had a lower $-\Delta G$ value, but clay soils had a much higher $-\Delta G$ value (Yawson et al., 2011). Gibb's free energy values varied between -3.79 to $-2.34\left(\mathrm{kcal}^{\mathrm{mol}}{ }^{-1}\right)$, with average values of $3.40,2.69,2.49$, and $2.71\left(\mathrm{kcal}^{\mathrm{mol}}{ }^{-1}\right)$ for the tested soil 1, 2, 3, and 4, respectively. The greatest $\Delta \mathrm{G}$ change of $\mathrm{K}^{+}$exchange in investigated soils was shown to be associated with decreased extractable $\mathrm{K}^{+}$. Increases in these chemical and soil $\mathrm{K}^{+}$parameters resulted in increases in $-\Delta \mathrm{G}$ values in soils, as seen by the strong connection of $\Delta \mathrm{G}$ with soil $\mathrm{pH}, \mathrm{CEC}$, organic matter, $\mathrm{K}_{\mathrm{L}}$, and $\mathrm{K}^{+}$reserves. The strong correlation between $-\Delta \mathrm{G}$ and $\mathrm{pH}$ indicates that when $\mathrm{pH}$ increases, less energy is required to remove one mol of $\mathrm{K}^{+}$from the solution. Furthermore, this might imply that lower $\mathrm{K}^{+}$content at equilibrium is more easily displaced than greater content, but releasing $\mathrm{K}^{+}$from $\mathrm{K}^{+}$reserves with the lowest $\mathrm{PBC}_{\mathrm{K}}$ values requires high energy (Yawson et al., 2011).

Table (3) shows the correlation coefficient and describes the link between various soil characteristics and K's thermodynamic parameters. Labile potassium $\left(\mathrm{K}_{\mathrm{L}}\right)$ was shown to be strongly associated with all other thermodynamic parameters, as well as soil characteristics examined. Except for clay content, EC, CEC and OM. $\mathrm{PBC}_{\mathrm{K}}$ values varied in soil samples and were strongly correlated with several characteristics of studied soils. Except for CEC, the levels of activity ratios at equilibrium $\left(\mathrm{AR}_{\mathrm{K}}{ }^{0}\right)$ were highly correlated with all of the characteristics of tested soils. Furthermore, all examined characteristics of tested soils including $\mathrm{pH}$ were adversely correlated with relative affinity or $K_{G}$ values. Also, there is a strong correlation between $-\Delta G$ and the examined soil characteristics; however, the correlation coefficient was not significant with clay content or CEC.

\section{Wheat yield vs thermodynamic parameters:}

Figure (3) illustrates the yield of wheat grown on studied soils. The yield obtained from potassium fertilization treatments using of $0,50,100,150 \%$ varied recording average value of $0.90,1.20,1.36,1.78 \mathrm{~g} \mathrm{pot}^{-1}, 1.53,2.09$, $2.32,2.14 \mathrm{~g} \mathrm{pot}^{-1}, 1.84,2.50,2.65,2.46 \mathrm{~g} \mathrm{pot}^{-1}{ }^{1} 0.83,1.18,2.17,1.78 \mathrm{~g} \mathrm{pot}^{-1}$ for soil $1,2,3,4$, respectively. When $\mathrm{K}$ levels raised from 0 to $150 \%$, wheat grains increased considerably. With compared to the control treatments, these 
J. Product. \& Dev., 26(4),2021

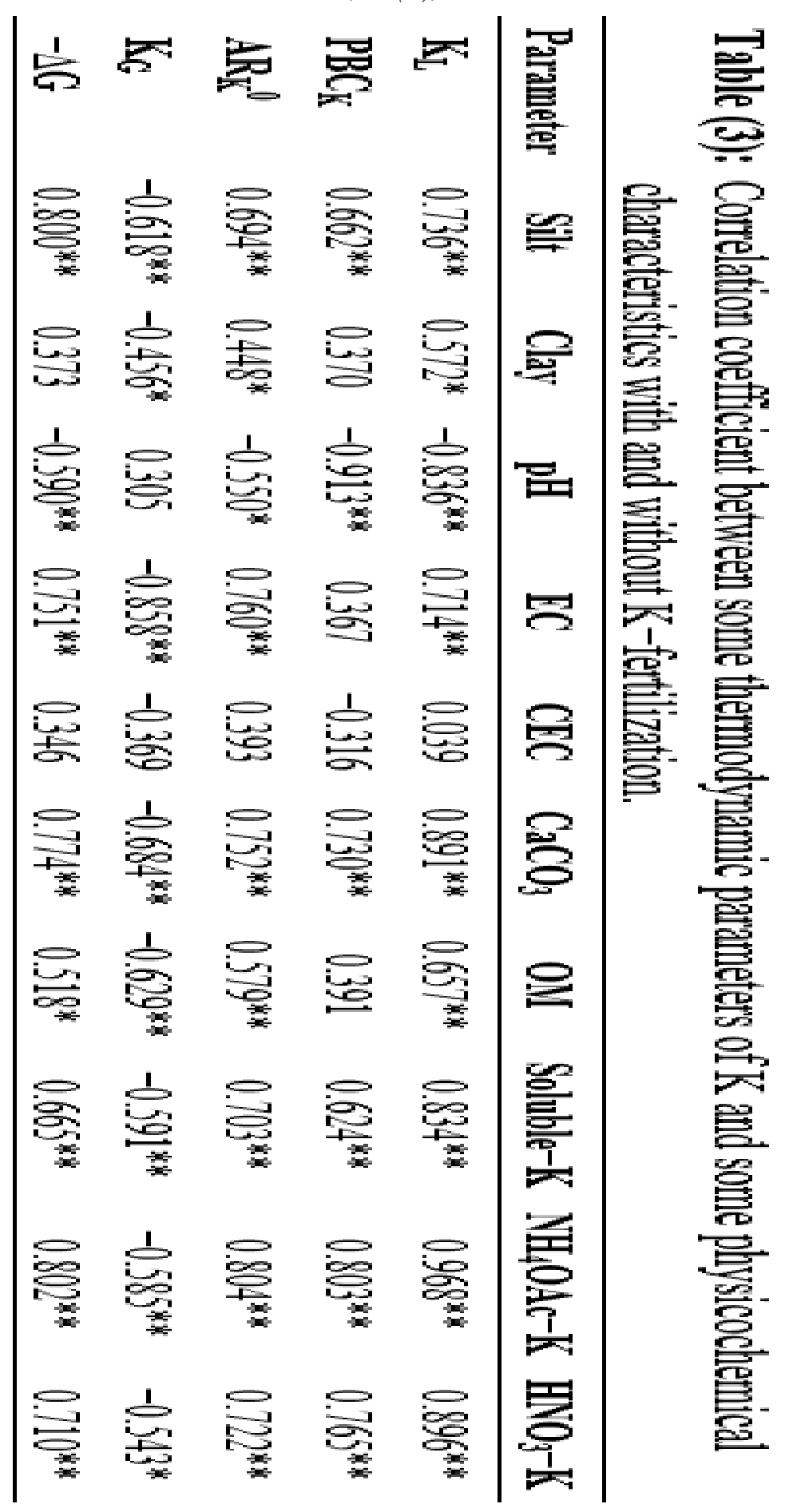




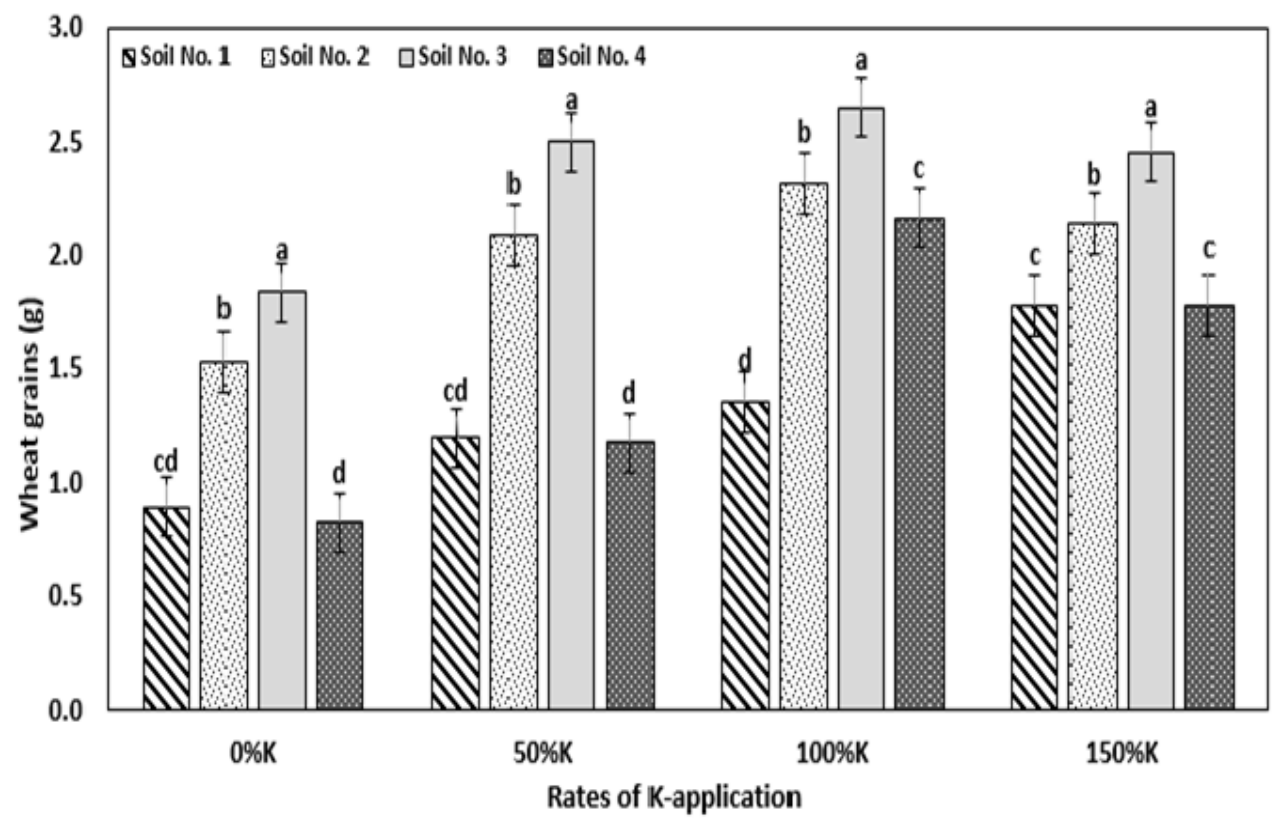

Fig. (3): Effect of interaction means between soil type and rates of $\mathrm{K}$-application of wheat yield (g).

increases were $97.8,39.87,33.70$, and $114.45 \%$ and $150 \%$. In soil 2 , on the other hand, wheat yield increased by $39.78 \%$.

In comparison to the other tested soils, soil 3 had the best treatment for wheat production, at $2.65 \mathrm{~g} \mathrm{pot}^{-1}$. This could be attributed to the high clay and silt content. Soil 1 and 4 have lower fertility than soils with high clay and silt content (Soil 2, 3). These findings are in line with those of Akhtar \& Khalid (2015), El-Defan et al. (2016), and Kubar et al. (2019), who found that applying $\mathrm{K}$ increases wheat yield and quality. Furthermore, the reduction of available $\mathrm{K}$ form led to decrease wheat yield and quality. This drop-in wheat production was more pronounced in the lowest $\mathrm{K}_{\mathrm{L}}$ of soil 1 and soil 4 than in the higher $\mathrm{K}_{\mathrm{L}}$ of soil 2, soil 3, and it was reflected in wheat yield.

\section{CONCLUSION}

The studied soil samples differed in their physical-chemical properties, i.e., soil texture, $\mathrm{EC}, \mathrm{pH}, \mathrm{OM}, \mathrm{CaCO}_{3}, \mathrm{CEC}$, water extracted- $\mathrm{K}, 1 \mathrm{M} \mathrm{NH}_{4} \mathrm{OAc}$ extracted-K., and $1 \mathrm{M} \mathrm{HNO}_{3}$ extracted-K. In this study, certain soils exhibited a high $\mathrm{K}$-intensity but a low $\mathrm{PBC}_{\mathrm{K}}$ content. In terms of relative affinity $\mathrm{K}_{\mathrm{G}}$ and Gibbs free energy $\Delta \mathrm{G}$, the situation was different. In general, the amounts of $\mathrm{AR}_{\mathrm{K}}{ }^{0},-\mathrm{K}^{0}$, and $\mathrm{PBC}_{\mathrm{K}}$ increased when the silt, clay content, $\mathrm{CEC}$ and organic matter of the soil samples tested increased. These findings were evident in the 
variance in wheat yield. It is suggested that organic amendments be applied to these soils, particularly the sandy ones, to enhance potassium status and the K Q/I relationship.

\section{ACKNOWLEDGEMENT}

Special thanks go to the Water and Soil Science staff and staff of Ismailia Research Center for their valuable help during this study.

\section{REFERENCES}

Abaslou, H., \& Abtahi, A. (2008). Potassium Quantity-Intensity Parameters and its Correlation with Selected Soil Properties in Some Soils of Iran. Journal of Applied Sciences, 8(10), 1875-1882. https://doi.org/ 10.3923/ jas.2008. 1875.1882

Al-Salam, Omar T., AL-Kaysi, S. C. (2013). Evaluation of available potassium determination methos for different texture soils. . Dually Journal of Agricultural Science, 5(1), 91-104.

Al obidi, M. A., Khalil, M. T., Desai, E. T. (2011). Study of potassium quantity-intensity parameters in some calcareous soils in Northern Iraq. El Rafdeen Agricultural Journal, 39(2), 1-9. https://search.emarefa.net/ detail/ BIM -358982\%0A\%0A

Akhtar E \& Khalid M (2015). Response of some wheat (Triticum aestivum L.) varieties to foliar application of $\mathrm{N} \& \mathrm{~K}$ under rainfed conditions. Pak J. Not ,38: 1027-1034.

Beckett, P. H. T. (1964a). Studies on soil potassium. Journal of Soil Science, 15(1), 1-8. https://doi.org/10.1111/j.1365-2389.1964.tb00239.x

Beckett, P. H. T. (1964b). Studies on soil potassium II. The 'immediate' q/i relations of labile potassium in the soil. Journal of Soil Science, 15(1), 923. https://doi.org/10.1111/j.1365-2389.1964.tb00240.x

Beckett, P. H. T., Craig J. B., \& Watson J. B. C. (1966). Studies in soil potassium v. the stability of Q/I relations by P. H. T. Beckett, J. B. Craig*, M. H. M. Nafady, and J. P. Watson**. 3, 435-455.

Cooke, G. W. (1979). Some priorities for british soil science1. Journal of Soil Science, 30(2), 187-213. https://doi.org/ 10.1111/j. 1365-2389. 1979. tb00978.x

Das, D., Dwivedi, B. S., Datta, S. P., Datta, S. C., Meena, M. C., Agarwal, B. K., Shahi, D. K., Singh, M., Chakraborty, D., \& Jaggi, S. (2019). Potassium supplying capacity of a red soil from eastern India after forty-two years of continuous cropping and fertilization. Geoderma, 341, 76-92. https://doi.org/10.1016/j.geoderma.2019.01.041 
El-Defan, T.A., El-Kholi ,H. M. A., Rifaat ,M. G. M. \& Abdallah, A. E. A. (2016). Effect of soil and foliar application of potassium on yield and mineral content of wheat grains grown in sandy soils. Egyptian J Agri Res., 77: 513-52

Estefan, G., Sommer, R., \& Ryan, J. (2013). Methods of soil, plant, and water analysis. A Manual for the West Asia and North Africa Region, 3.

Evangelou, V. P., Wang, J., \& Phillips, R. E. (1994). New Developments and Perspectives on Soil Potassium Quantity/Intensity Relationships (pp. 173-227). https://doi.org/10.1016/S0065-2113(08)60624-0

Griffin, B. A., \& Jurinak, J. J. (1973). Estimation of activity coefficients from the electrical conductivity of natural aquatic systems and soil extracts. Soil Science, 116(1), 26-30. https://doi.org/10.1097/00010694197307000-00005

Hamed, M. H., \& Amin, A. E. Z. (2017). Evaluation of Potassium Quantity-Intensity in some Soils of El-Dakhla Oasis, New Valley, Egypt. Alexandria Science Exchange Journal: An International Quarterly Journal of Science Agricultural Environments, 38(January-March), 112-119. https:// doi.org/10. 21608/ asejaiqjsae. 2017. 2367

Islam, A., Karim, A. J. M. S., Solaiman, A. R. M., Islam, M. S., \& Saleque, M. A. (2017). Eight-year long potassium fertilization effects on quantity/intensity relationship of soil potassium under double rice cropping. Soil and Tillage Research, 169, 99-117. https://doi.org/10. 1016/j. still.2017. 02.002

Jagadeesh, B.R., Jayaprakash, S.M., Sudhir, K. (2005). Quantity-intensity parameters of potassium in soils of some selected agroclimatic zones of Karnataka. Mysore J. Agric. Sci., 39, 490-497.

Jiang, N., Hu, B., Wang, X., Meng, Y., Chen, B., \& Zhou, Z. (2019). Effects of crop residue incorporation and inorganic potassium fertilization on soil potassium supply power. Archives of Agronomy and Soil Science, 65(9), 1223-1236. https://doi.org/10.1080/03650340.2018.1562174

Khamis, M. A. (2000). Evaluation of poultry manure and rice straw as sources of potassium for potato in sandy loam soil. Egyptian Journal of Soil Science, 40(4), 437-452.

Krauss, A. (2000). Potassium, integral part for sustained soil fertility. Potassium and Phosphorus: Fertilisation Effect on Soil and Crops. Proceedings of the Regional IPI Workshop, Lithuania, 23-24 October, 2000, 7-19. 
Krauss, Adolf, \& Krauss, A. (2002). Potassium, an integral part for sustained soil fertility and efficient crop production. 222, 5-17. http://apps.webofknowledge.com/full_record.do?product=UA\&search_m ode=GeneralSearch\&qid=30\&SID=Y1@E@mL2goO9i@hhLGL\&page $=3 \&$ doc $=128 \&$ cacheurlFromRightClick $=$ no

Kubar, G. M., Talpur, K. H., Kandhro, M. N., Khashkhali, S., Nizamani, M. M., Kubar, M. S., \& Kubar, A. A. (2019). 27. Effect of potassium $(\mathrm{K}+)$ on growth, yield components and macronutrient accumulation in Wheat crop. Pure and Applied Biology (PAB), 8(1), 248-255.

Manahan, S. E. (2017). Environmental Chemistry 10th Edition $\left(10^{\text {th }}\right.$ ed.). CRC Press.

Panda, R., \& Patra, S. K. (2018). Quantity-intensity relations of potassium in representative coastal soils of eastern India. Geoderma, 332, 198-206. https://doi.org/10.1016/j.geoderma.2018.07.014

Pasricha, N. S., \& Bansal, S. K. (2002). Potassium fertility of Indian bench-mark soils. Potassium for Sustainable Crop Production (NS Pasricha and SK Bansal, Ed.), 124-150.

Samadi, A. (2006). Potassium exchange isotherms as a plant availability index in selected calcareous soils of western Azarbaijan Province, Iran. Turkish Journal of Agriculture and Forestry, 30(3), 213-222. https://doi.org/ 10.3906/tar- 502-8

Simard, R. R., Zizka, J., \& De Kimpe, C. R. (1992). Release of Potassium and Magnesium from Soil Fractions and Its Kinetics. Soil Science Society of America Journal, 56(5), 1421-1428. https://doi.org/ 10.2136/ sssaj1992. 03615995005600050015x

Sparks, D. L. (1998). Soil physical chemistry. CRC press.

Sparks, D. L. (2000). 1.4 Bioavailability of Soil Potassium. In Handbook Of Soil. C. R. C. Press, New York.

Subba, R. A., Srivastava, T. R. (2001). Assessing potassium availability in India. (eds) N. S. Pasricha and S. K Bansol. Potassium In Indian Agriculture. Potash Institutes, Basel, Switzerland, 125-157.

Surapaneni, A., Palmer, A. S., Tillman, R. W., Kirkman, J. H., \& Gregg, P. E. H. (2002). The mineralogy and potassium supplying power of some loessial and related soils of New Zealand. Geoderma, 110(3-4), 191-204.

Suttanukool, P., Darunsontaya, T., \& Jindaluang, W. (2019). A Study on the Quantity/Intensity Relationships of Potassium of Sugarcane Growing Soils, Eastern Thailand. Communications in Soil Science and Plant Analysis, 50(2), 153-163. https://doi.org/ 10.1080/ 00103624. 2018. 1556287. 
Wang, J. J., Harrell, D. L., \& Bell, P. F. (2004). Potassium Buffering Characteristics of Three Soils Low in Exchangeable Potassium. Soil Science Society of America Journal, 68(2): 654-661. https://doi.org/ 10.2136/ sssaj2004. 540

Woodruff, C. M. (1955a). Ionic Equilibria between Clay and Dilute Salt Solutions. Soil Science Society of America Journal, 19(1), 36-40. https://doi.org/10.2136/sssaj1955.03615995001900010008x

Woodruff, C. M. (1955b). The Energies of Replacement of Calcium by Potassium in Soils. Soil Science Society of America Journal, 19(2), 167171. https://doi.org/10.2136/sssaj1955.03615995001900020014x

Yawson, D. O., Kwakye, P. K., Armah, F. A., \& Frimpong, K. A. (2011). The dynamics of potassium $(K)$ in representative soil series of Ghana.

Zarrabi, M., \& Jalali, M. (2008). Evaluation of Extractants and QuantityIntensity Relationship for Estimation of Available Potassium in Some Calcareous Soils of Western Iran. Communications in Soil Science and Plant Analysis, 39 (17-18), 2663-2677.https://doi.org/10.1080/00 103620802358797.

Zhu, D., Lu, J., Cong, R., Ren, T., Zhang, W., \& Li, X. (2020). Potassium management effects on quantity/intensity relationship of soil potassium under rice-oilseed rape rotation system. Archives of Agronomy and Soil Science, 66(9), 1274-1287. https://doi.org/10. 1080/03650340 .2019. 1663830. https://geohack.toolforge.org/
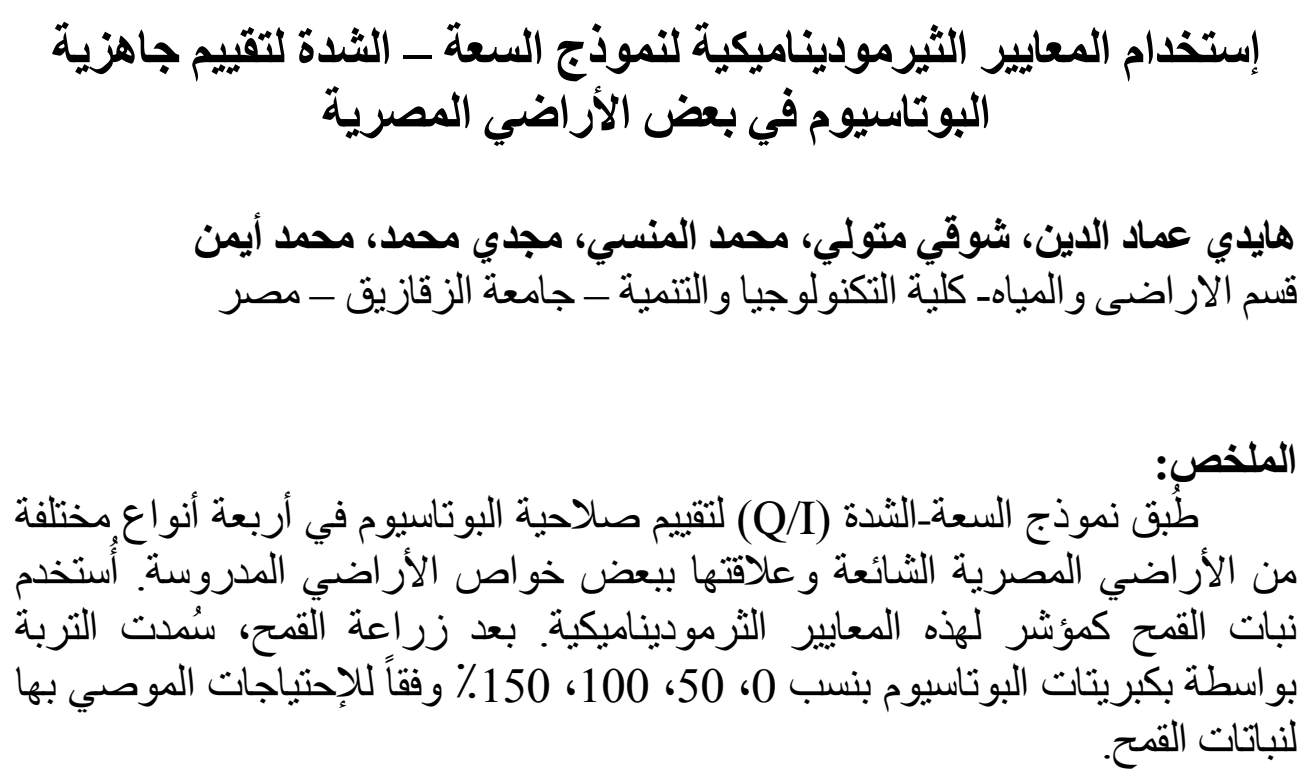


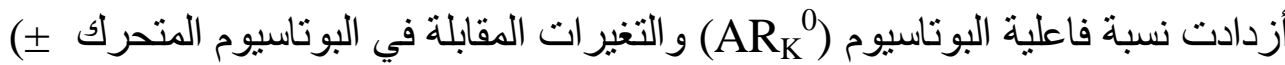

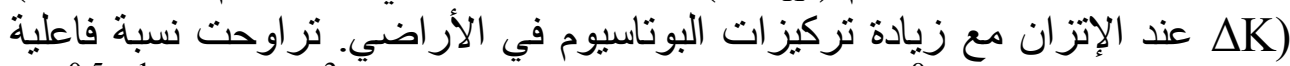

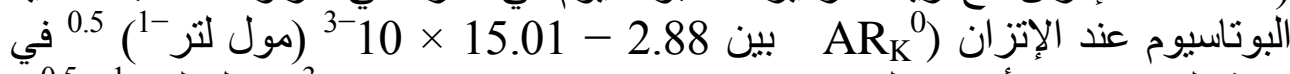

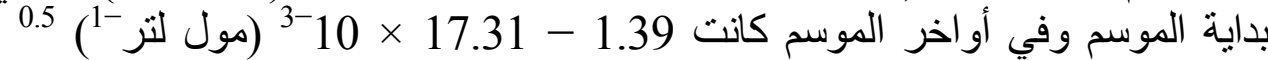

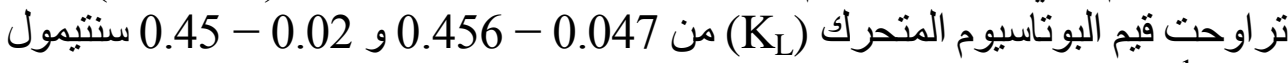

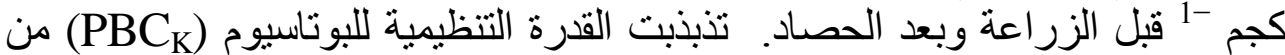

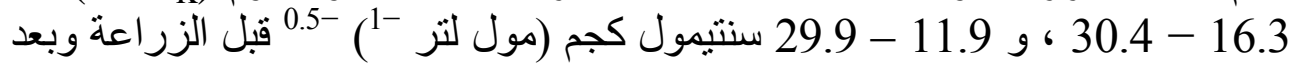

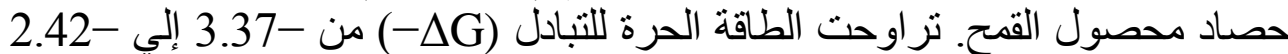

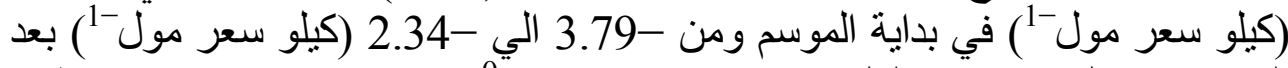

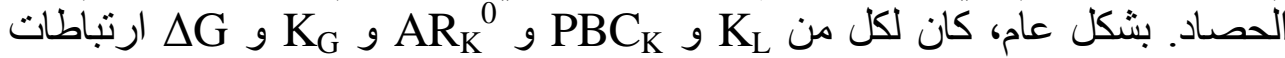

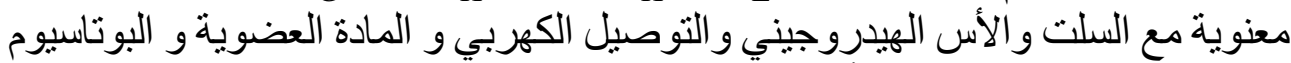

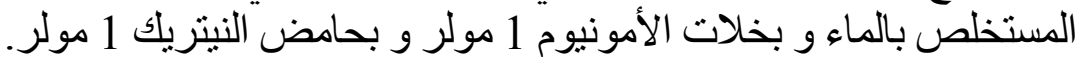

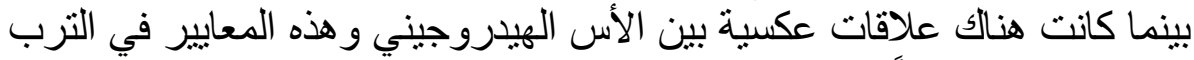

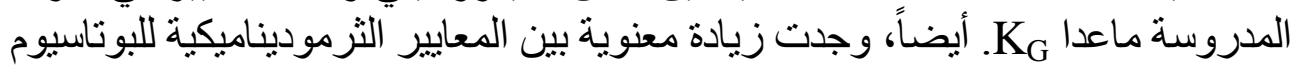

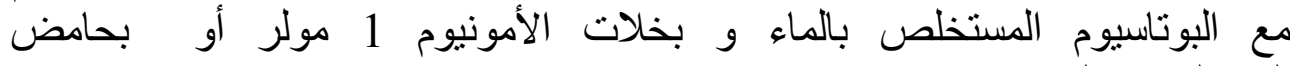

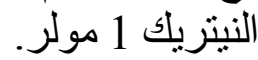
التوصية : نستتنج أن هنالك علاقة ارتباط معنوية بين هذه المعايير الثرموديناميكية مع دع

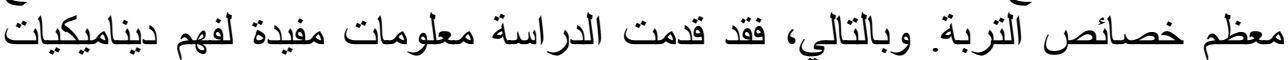
البوتاسيوم في التربة الدصرية الثائعة وتقديم مساهمة كبيرة في إدارة البونائاسيوم في تللك الأر اضي. الكلمات الدالة: منحنى السعة/الثندة؛ المعايير الثنيرموديناميكية؛ صور البوتاسيوم؛ نسبة فعالية البوتاسيوم؛ الطاقة الحرة. 
